\title{
THE EFFECT OF PIOGLITAZONE ON INTIMAL HYPERPLASIA OF VENOUS BRIDGE VASCULAR
}

\author{
HONGGUANG LU ${ }^{1}$, SHUANG LI ${ }^{2}$, YANKUN HAO ${ }^{2}$, GUANGNAN LI ${ }^{3}$, FUBO ZHOU $^{4 *}$ \\ ${ }^{1}$ Department of Cardiovascular Surgery, The Fourth Affiliated Hospital of Harbin Medical University, Harbin, 150001, China \\ ${ }^{2}$ Medical Functional Laboratory, Mudanjiang Medical University, Mudanjiang,157011, China \\ ${ }^{3}$ Department of Cardiology, The Fourth Affiliated Hospital of Harbin Medical University, Harbin, 150001, China \\ ${ }^{4}$ Department of Pharmacology, Mudanjiang Medical University, Mudanjiang, 157011, China
}

*corresponding author: zhoufubo19890122@163.com

Manuscript received: January 2020

\begin{abstract}
This study aimed to analyse the effect of pioglitazone (PIO) on intimal hyperplasia of venous bridge vascular using a murine model of vein transplantation. The rats were treated with $3 \mathrm{mg} / \mathrm{kg}$ bw PIO one week before modelling and for 2 and 4 weeks after modelling. The thickness and changes of vascular intima were analysed by histopathology and the expression of phosphorylated extracellular signal-regulated kinase (p-ERK1/2) protein in rat venous bridges was detected by Western blotting. The results showed that the blood vessels in the model group at 2 and 4 weeks after modelling (NC4) had a significantly increased membrane thickness ratio compared with the sham-operated group (NO4). PIO treatment significantly decreased the membrane thickness ratio and the venous bridge cell components compared with the model group indicating that PIO could inhibit the intima thickening of the venous bridge. Regarding the p-ERK1/2 levels, PIO treatment significantly decreases the upregulation of p-ERK1/2 observed in the model group. Therefore, it can be concluded that PIO could effectively alleviate intimal hyperplasia after venous bridge vascular transplantation, and inhibit the expression of p-ERK1/2 and the proliferation of vascular smooth muscle cells (VSMCs).
\end{abstract}

\section{Rezumat}

Acest studiu a avut ca scop analiza efectului pioglitazonei (PIO) asupra hiperplaziei intimei a patului vascular venos, utilizând un model murin de transplant venos. Şobolanii au fost tratați cu $3 \mathrm{mg} / \mathrm{kg}$ corp PIO cu o săptămână înainte de inducerea hiperplaziei și după 2 și 4 săptămâni. Modificările intimei vasculare au fost analizate prin determinări histopatologice şi expresia proteinkinazei extracelulare fosforilate (p-ERK1/2) în punțile venoase a fost determinată prin tehnica Western blot. Rezultatele au arătat că vasele de sânge din lotul experimental la 2 și 4 săptămâni după modelare au avut un raport semnificativ crescut al grosimii membranei în comparație cu grupul de control. În ceea ce privește valorile p-ERK1/2, tratamentul PIO scade semnificativ up-reglarea p-ERK1/2 observată în grupul de control. Prin urmare, se poate concluziona că PIO ar putea atenua în mod eficient hiperplazia intimei după transplantul venos și inhibă expresia p-ERK1/2 precum și proliferarea celulelor musculare netede de origine vasculară (VSMC).

Keywords: pioglitazone, venous bridge vascular, intimal hyperplasia, p-ERK1/2

\section{Introduction}

Coronary atherosclerotic heart disease, also known as "coronary heart disease", is caused by atherosclerotic lesions in coronary arteries [1]. Coronary artery bypass grafting $(\mathrm{CABG})$ is the best method for treating this disease, such as autologous saphenous vein transplantation [2]. This method has a lot of advantages, but can also affect the flow of blood after surgery, leading to the proliferation of the intima of the venous bridge. The physiological mechanism of the proliferation of the intima of the venous bridge vascular is associated with the increase of vascular smooth muscle cell (VSMC) and extracellular matrix deposition that lead to lesions of the grafted vein level [3, 4]. PLC $\gamma$ ERK1/2-RAF1-MEK-ERK1/2 is the core pathway associated with the function of vascular endothelial cells [5]. Erk1/2 is a member of the mitogen-activated protein kinase (MAPK) family, which promotes cell proliferation. Previous studies have shown that ERK1/2 and p-ERK1/2 after activation are closely related to vascular remodelling in rats, and ERK1/2 has a significant influence on the proliferation of smooth muscle cells and endocardial thickening [6].

PPAR- $\gamma$ and its ligand were found to be expressed in VSMCs, endothelial cells, and cardiac muscle cells to different degrees [7]. Thiazolidinediones can reduce the incidence of coronary stent restenosis. Pioglitazone (PIO) is a thiazolidinedione drug that acts as an activator of synthetic PPAR- $\gamma$, which can inhibit the inflammatory response of blood vessels [8]. PIO can protect blood vessels in vascular remodelling caused by hypertension, having a multi-target role in regulating the expression of some essential genes in vascular endothelial cells and smooth muscle cells, that leads to the improvement 
of the pathophysiological process of central vascular diseases [9]. The effect of blood flow on the vessel wall after venous bridge transplantation is similar to that of vascular remodelling. Therefore, in this study, we aimed to analyse the effect of PIO on intimal hyperplasia of venous bridge vascular on a murine model of vein transplantation.

\section{Materials and Methods}

\section{Animals}

Thirty Sprague-Dawley (CD-SD) healthy and clean grade male rats with a weight of $225 \pm 25 \mathrm{~g}$, provided by Shanghai Slack Experimental Animal Co Ltd., China, were selected for this experiment. The animals were kept in cages without specific pathogen (SPF) at $23 \pm$ $2^{\circ} \mathrm{C}$ and relative humidity of $50 \pm 5 \%$. The rats were allowed free access to water and food and with $12 \mathrm{~h}$ of light a day, alternating between day and night. The ethics committee of The Fourth Affiliated Hospital of Harbin Medical University, Harbin, China, approved the protocol, and the experiment also followed the regulations of the State Science and Technology Commission on the management of laboratory animals.

\section{Animal Groups}

The animals were randomly divided into two groups: the experimental group (10 animals per group) and the control group (20 animals per group). Rats in the experimental group received ( $3 \mathrm{mg} / \mathrm{kg} \mathrm{bw})$ pioglitazone by gavage one week before modelling and on the whole observation period after the modelling. In contrast, the rats in the control group received the same amount of normal saline by gavage. The control group was subdivided into the placebo group, 10 animals per group that underwent ipsilateral autogenous external jugular vein - common carotid artery transplantation in the right vein and subdivided into 2 subgroups based on the moment of sacrification $14^{\text {th }}$ day $(\mathrm{NC} 2)$ or $28^{\text {th }}$ day (NC4), and a sham-operated group, 10 animals per group, to which the left vein was untreated, subdivided into 2 subgroups based on the moment of sacrification (NO2 and NO4) (Table I). The experimental group was subdivided into PIO2 group in which the rats were sacrificed in the day $14^{\text {th }}$ after modelling, and PIO4 group in which the rats were sacrificed in the day $28^{\text {th }}$ after modelling (Table I).

Table I

Experimental groups

\begin{tabular}{|l|l|c|c|c|c|}
\hline \multicolumn{1}{|c|}{ Group } & \multicolumn{1}{|c|}{ Group } & No. & Number of rats & No. & Number of rats \\
\hline \multirow{2}{*}{ Control group } & Sham-operated group & N02 & 5 & N04 & 5 \\
\cline { 2 - 6 } & Placebo group & NC2 & 5 & NC4 & 5 \\
\hline Experimental group & Pioglitazone group & PIO2 & 5 & PIO4 & 5 \\
\hline
\end{tabular}

A rat model of venous bridge transplantation

Rats fasted $12 \mathrm{~h}$ before surgery and then anaesthetized by intraperitoneal injection of $300 \mathrm{mg} / \mathrm{kg}$ bw $10 \%$ chloral hydrate (Tianjin Hedong District Hongyan Reagent Factory, China). After anaesthesia, $200 \mathrm{U} / \mathrm{kg}$ bw heparin sodium (Tianjin Biochem Pharmaceutical Co Ltd, China) was injected into the tail vein and the head and limbs of the rats were fixed supine, the hair was removed, and the skin of the right-centre of the neck was disinfected. After longitudinal incision, the external jugular vein of $1.5 \mathrm{~cm}$ was separated. The distal and proximal ends of the main jugular vein and its important branches were ligated. The middle vena jugularis externa of about $0.8 \sim 1 \mathrm{~cm}$ was cut, and the mixed solution of $0.12 \mathrm{~g} / \mathrm{L}$ papaverine and 12,500 U/L heparin sodium was used to gently wash the middle vena jugularis externa until the blood vessel wall became white, and then it was soaked in heparin sodium salt for later use. The common carotid artery sheath under the right sternocleidomastoid muscle was separated, and $0.5 \mathrm{~cm}$ of the middle artery was taken after blocking the blood flow at both ends of the blood vessel and washed with heparin sodium salt. The traction arterial stump was passed through a special cuff with a polyester sheath and ligated and fixed. The venous bridge was inverted on the cuff tube, and the telecentric end and the proximal end of the blood vessel were sequentially opened after ligation and fixation. The vascular patency was determined by filling degree and pulsation of the venous bridge. The wound was sutured and disinfected with iodophor (Tianjin Biochem Pharmaceutical Co Ltd, China).

The rats were observed twice per day in the morning and evening after surgery, and the wound was treated with iodophor for disinfection and an intramuscular injection of penicillin (Tianjin Biochem Pharmaceutical Co Ltd, China) to prevent infections.

Sample collection method

The grafted vein of each group and the contralateral vein of the sham operation group were excised on the $14^{\text {th }}$ and $28^{\text {th }}$ days after surgery, respectively. Rats fasted $12 \mathrm{~h}$ before surgery and then anaesthetized by intraperitoneal injection of $300 \mathrm{mg} / \mathrm{kg}$ bw $10 \%$ chloral hydrate (Tianjin Hedong District Hongyan Reagent Factory, China). The rats were fixed in a supine position and disinfected. The skin and tissues were cut, and the venous bridge vessels at the upper and lower ends were ligated with a 4-0 polyester thread. The venous bridge was cut at a distance of about $0.3 \mathrm{~mm}$ from the edge of the cuff tube and washed with saline. The obtained samples were cut in two halves, one for the histopathological sections and the other half for the Western blot. 
Preparation of intima section of grafted vein The obtained vein bridges were fixed in $4 \%$ formaldehyde and then used for obtaining the paraffin blocks based on standard procedure. The paraffin blocks were then cut into slices of 5 microns and stained with haematoxylin-eosin (HE) and observed by an optical microscope. The thickness of intima and media were measured 4 times in each sample, and the ratio of intima thickness to media thickness was calculated. Method for detecting the expression of $p-E R K 1 / 2$ by Western blotting

Blood vessel samples were rapidly ground into a powder with liquid nitrogen and placed in $1.5 \mathrm{~mL}$ centrifuge tube. RIPA (radioimmunoprecipitation assay) lysate (Tianjin Biochem Pharmaceutical Co Ltd, China) was added to crack the samples on ice for $30 \mathrm{~min}$, and then the sample was placed in a cryogenic freezing centrifuge (Beijing Fourth Ring Road Scientific Instrument Factory, China) at $4^{\circ} \mathrm{C}$ and centrifuged at $12000 \mathrm{rpm}$ for $15 \mathrm{~min}$. The supernatant was placed in a new $0.6 \mathrm{~mL}$ microcentrifuge $(\mathrm{EP})$ tube. The BSA (bovine serum albumin) standard curve was used to detect the total protein concentration in the sample. After the sample was diluted with the protein loading buffer, the protein was denatured by a metal bath at $95^{\circ} \mathrm{C}$. The $12 \%$ separation gel was prepared and loaded, and the protein in the sample was separated by electrophoresis at $100 \mathrm{~V}$. After $90 \mathrm{~min}$, the separation gel was cut and transferred at $100 \mathrm{~V}$ for $90 \mathrm{~min}$. After the end of the film transfer, it was washed with buffer fluid and sealed overnight with sealing fluid. Subsequently, it was incubated overnight in a table concentrator at $4^{\circ} \mathrm{C}$ with diluted pika anti-rat p-ERK1/2 primary antibody (1:2000) (Tianjin Biochem Pharmaceutical Co Ltd, China) and rabbit anti-rat t-ERK1/2 internal reference antibody (1:2000) (Tianjin Biochem Pharmaceutical Co Ltd, China). After incubation, the fills were washed 4 times with phosphate-buffered saline (PBS) for 15 min each time and $20 \mathrm{~mL}$ diluted goat anti-rabbit HRPIgG secondary antibody $(1: 10,000)$ (Tianjin Biochem Pharmaceutical Co Ltd, China) was added and incubated in a table concentrator at room temperature for $1 \mathrm{~h}$, and then washed with PBS for 4 times, each time for 15 min. Finally, diaminobenzidine (DAB) colour rendering solution (Tianjin Biochem Pharmaceutical Co Ltd, China) was added, and Image pro plus Image analysis software (BIO-RAD, USA) was used to analyse the target band. The death grayscale values of the target band and t-ERK1/2 protein were compared, and the relative expression levels were calculated.

\section{Statistical analysis}

The experimental results were expressed as mean \pm standard deviation. SPSS16.00 statistical software was used for statistical processing. Student's t-test was used for the comparison of results between the two groups, and comparisons of results greater than the two groups were analysed by one-way ANOVA. A value of $\mathrm{p}<0.05$ is considered a significant difference, and a value of $p<0.01$ is considered an extremely significant difference.

\section{Results and Discussion}

The establishment of venous transplantation model In this experiment, a rat model of venous bridge transplantation was successfully established with the method of autologous right external jugular vein transplantation to the ipsilateral common carotid artery. The vein transplantation was successfully performed and the postoperative venous bridge was observed to be well filled with blood. During the venous bridge sampling process, if the distal cardiac end of the venous bridge was cut off, blood was gushing out, indicating that the modelling was successful (Figure 1).
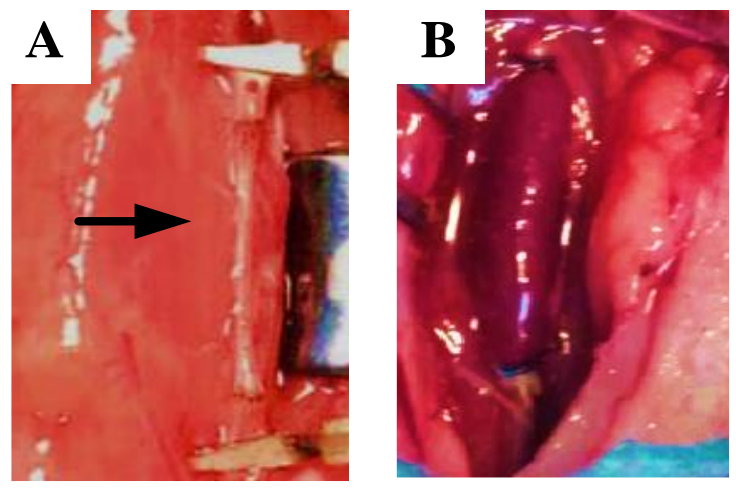

Figure 1.

Effect of external jugular vein transplantation in rats (A. Treatment of vascular anastomosis; B. Venous bridge vascular filling)

\section{Histological observation}

As can be observed from Figure 2A and Figure 2B, in the N02 and N04 sham operation group, the venous blood vessel wall of the rats was thin, and the structure was normal. The intima was composed of a layer of tightly arranged endothelial cells, and the media was composed of 2 - 3 layers of VSMCs. As shown in Figure 2C and Figure 2D, two weeks after vein transplantation, the membrane of vein bridge of rats in $\mathrm{NC} 2$ and $\mathrm{NC} 4$ placebo groups contained a large number of irregularly arranged VSMCs, the membrane was significantly thickened, and the number of inner subcutaneous cells increased. During the four weeks of vein grafting, the number of irregularly arranged VSMCs in the membrane increased, along with the number of smooth muscle cells in the membrane. As shown in Figure 2E and Figure 2F, cell components in each layer of the vein bridge in PIO2 and PIO4 pioglitazone groups were significantly increased compared with the sham operation group. However, compared with the placebo group, the venous bridge cell components of the pioglitazone group were reduced considerably, and the tissue structure was clearly arranged. 

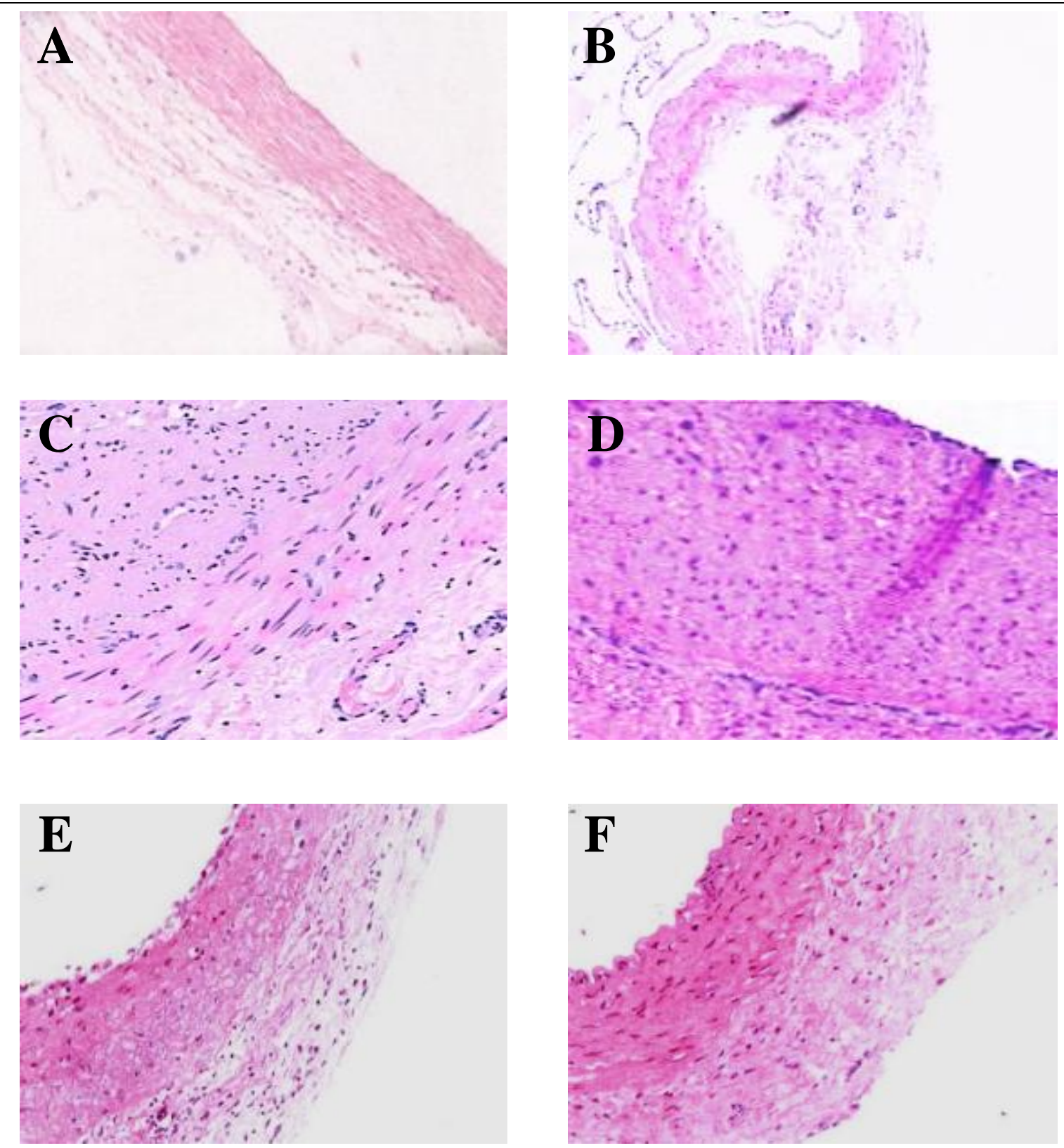

Figure 2.

Section of the venous bridge

(A: N02 group; B: N04 group; C: NC2 group; D: NC4 group; E: PIO2 group; F: PIO4 group)

The intima and media thickness of the veins were measured and compared. As shown in Figure 3A, the intima of the venous bridge in the placebo group (NC2 $=25.43 \pm 0.90 \mu \mathrm{m})$ was significantly thickened compared with that in the N0 sham-operated group $(\mathrm{NO} 2=4.13 \pm 0.84 \mu \mathrm{m})(\mathrm{p}<0.01)$. As shown in Figure $3 \mathrm{~B}$, the intima of the venous bridge in rats in $\mathrm{NC}$ placebo group $(\mathrm{NC} 4=35.71 \pm 1.10 \mu \mathrm{m})$ was significantly thickened $(\mathrm{p}<0.01)$ and the intima thickness $(\mathrm{PIO} 2=8.57 \pm 1.63 \mu \mathrm{m}, \mathrm{PIO} 4=10.66 \pm$ $1.35 \mu \mathrm{m})$ was significantly reduced $(\mathrm{p}<0.01)$ after 4 weeks of treatment compared with that at two weeks after treatment. It can be observed from Figure $3 \mathrm{C}$ that the ratio of $\mathrm{NC} 2$ was significantly increased compared to N02 ( $<<0.05)$, and the ratio of NC4 was significantly increased compared with N04 ( $p<0.01$ ), while the ratio of intima-media thickness after PIO was significantly reduced compared to $\mathrm{NC}$ group $(\mathrm{p}<0.01)$, and the ratio of intima-media thickness after 4 weeks of treatment was extremely significantly reduced compared with that after 2 weeks of treatment $(\mathrm{p}<0.01)$.

Expression of p-ERK1/2 proteins

The $\mathrm{p}-\mathrm{ERK} 1 / 2$ protein expression of the venous bridge in the placebo group at 2 and 4 months after modelling (NC2 and NC4) significantly increase compared with the level in the sham-operated group (NO2 and NO4). The treatment with pioglitazone significantly decreases the protein expression of $\mathrm{p}$-ERK $1 / 2$ compared to the placebo group at each time points (Figures 4 and 5). 


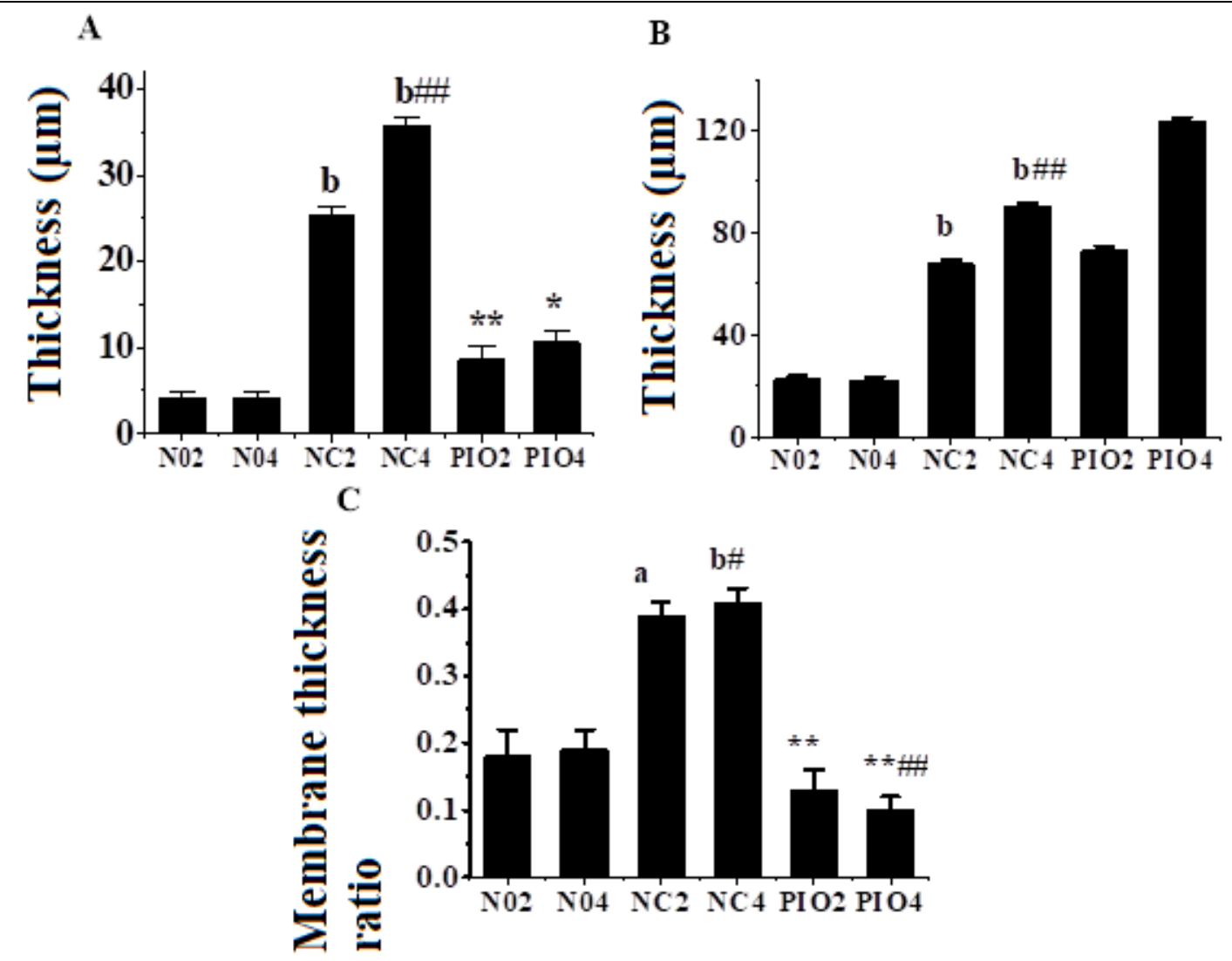

Figure 3.

Comparison of cell membrane thickness

(A: change in the thickness of the intima; B: changes in the thickness of the tunica media; $\mathrm{C}$ : thickness of tunica media and intima ratio). Comparison with N0 group in the same period: $\mathrm{a}$ : $\mathrm{p}<0.05 ; \mathrm{b}: \mathrm{p}<0.01$; Comparison with NC group: **: $\mathrm{p}<0.01$; Comparison between 2 weeks and 4 weeks after surgery in the same group: \#: $p<0.05$, \#\#: $p<0.01$

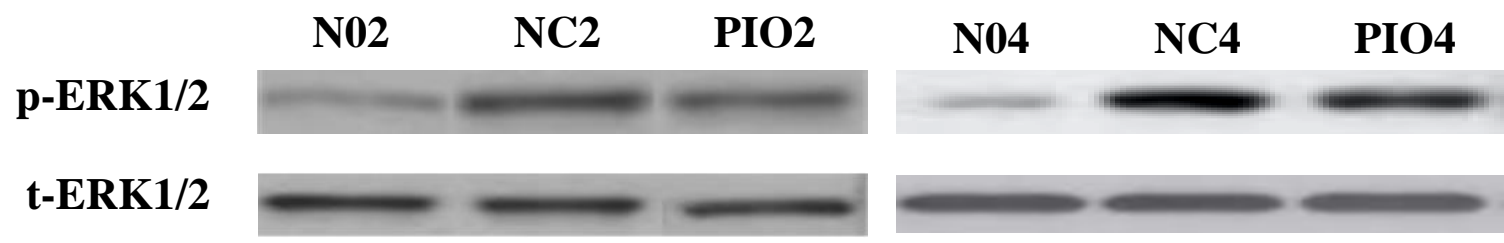

Figure 4.

Results regarding the expression of $\mathrm{p}-\mathrm{ERK} 1 / 2$ protein of venous bridge in each group

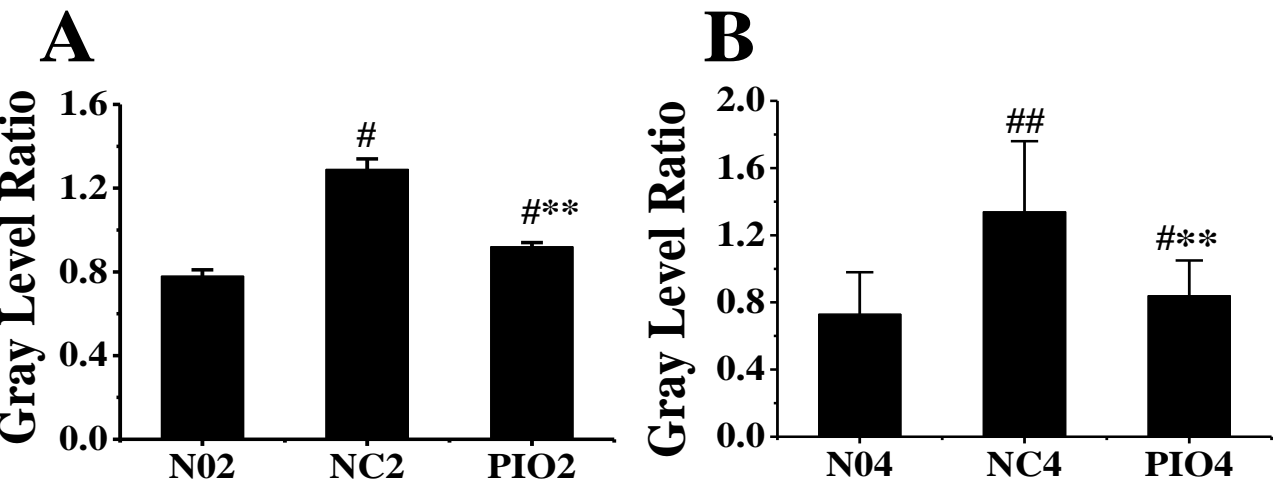

Figure 5.

Comparison of grey values of p-ERK1/2 protein in venous bridges of each group. Compared with N0 group, \#: $\mathrm{p}<0.05$, \#\#: $\mathrm{p}<0.01$; compared with NC group **: $\mathrm{p}<0.01$ 
Thiazolidinediones can inhibit the proliferation of vascular smooth muscle cells and control the proliferation of new vascular intima. Studies have shown that PIO may reduce intimal hyperplasia [10]. PIO can regulate the expression of PPAR $\gamma$ protein in vascular smooth muscle cells to improve insulin resistance [11], and the proliferation, differentiation, and migration of smooth muscle cells play a key role in venous bridge stenosis. In this experiment, CD-SD rats were used to establish the rat models with venous bridge transplantation, and the pathological sections of venous bridge in each group were measured. The results showed that compared with the sham-operated group, a large number of chaotic VSMCs were found in the intima and tunica media of the placebo group rats two weeks after the operation, accompanied by a certain degree of vascular wall thickening, which was more serious four weeks after the operation. Compared with the placebo group, the cell composition of each layer of the venous bridge in the PIO group was significantly reduced, the tissue structure was clearly arranged, the intima thickness and the ratio of the intima thickness and tunica media thickness were also considerably reduced. Therefore, it can be concluded that PIO could significantly slow down the proliferation of venous bridge vessels, which was consistent with the results of the study of Langenfeld et al. where high-dose PIO reduced the middle thickness of carotid intima [12].

Platelet-derived growth factors induce the expression of p-ERK1/2, thereby regulating the ERK signalling pathway and inhibiting the proliferation of vascular smooth muscle cells $[13,14]$. Lu et al. found that the ERK1/2 MAPK signalling pathway can inhibit the proliferation of vascular smooth muscle cells [15]. Moreover, studies have shown that PIO can inhibit the abnormal activation and proliferation of VSMCs, which is closely related to the inhibition of ERK1/2 activity [16, 17]. In this experiment, the level of ERK1/2 proteins in venous bridges in each group were analysed by Western blotting. It was found that the expression of ERK1/2 in the venous bridge of rats in the PIO group was significantly decreased compared with that in the placebo group, indicating that ERK1/2 protein is implicated in the mechanism through which PIO protects against vascular intimal hyperplasia in the venous bridge.

\section{Conclusions}

In conclusion, PIO has therapeutic effects on intimal hyperplasia after venous bridge transplantation, by down-regulating the expression of ERK1/2 protein and inhibiting the proliferation of VSMCs. However, whether PIO also has other target pathways than the ERK1/2 pathway and how these sites interact with each other to achieve the therapeutic effect needs to be further studied.

\section{Acknowledgement}

This work was supported by The Scientific research projects of basic scientific research in colleges and universities operating expenses of Heilongjiang Province in 2018, China (Grant No. 2018-KYYWFMY-0014) and The Health Commission of Heilongjiang Province Project (2014-376).

\section{Conflict of interest}

The authors declare no conflict of interest.

\section{References}

1. Frestad D, Prescott E, Vital exhaustion and coronary heart disease risk. Psychosom Med., 2017; 79(3): 260272.

2. Taggart DP, Amin S, Djordjevic J, Oikonomou EK, Thomas S, Kampoli AM, Sabharwal N, Antoniades C, Krasopoulos G, A prospective study of external stenting of saphenous vein grafts to the right coronary artery: the VEST II study. Eur J Cardiothorac Surg., 2017; 51(5): 952-958.

3. Osgood MJ, Sexton K, Voskresensky I, Hocking K, Song J, Komalavilas P, Brophy C, Cheung-Flynn J, Use of Brilliant Blue FCF during vein graft preparation inhibits intimal hyperplasia. J Vasc Surg., 2016; 64(2): 471-478.

4. Cheung AK, Imrey PB, Alpers CE, Robbin ML, Radeva M, Larive B, Shiu YT, Allon M, Dember LM, Greene T, Himmelfarb J, Roy-Chaudhury P, Terry CM, Vazquez MA, Kusek JW, Feldman HI, Hemodialysis Fistula Maturation Study Group, Intimal hyperplasia, stenosis, and arteriovenous fistula maturation failure in the hemodialysis fistula maturation study. J Am Soc Nephrol., 2017; 28(10): 3005-3013.

5. Mountain DJ, Tummers M, Kirkpatrick SS, Cassada DC, Stevens SL, Freeman MB, Grandas O, PS214. Estrogen stimulates the cellular processes of intimal hyperplasia development via ERK1/2 dependent signaling cascades. J Vasc Surg., 2010; 51(6): 74S-75S.

6. Lee J, Lee CY, Seo HH, Bazarragchaa B, Batdelger G, Choi S, Hwang KC, Lee S, Lim S, Extract of Oxytropis pseudoglandulosa inhibits vascular smooth muscle cell proliferation and migration via suppression of ERK1/2 and AKT signaling pathways1. Clin Hemorheology Microcirc., 2018; 69(1-2): 277-287.

7. Rautureau Y, Paradis P, Schiffrin EL, Generation of a mouse model with smooth muscle cell specific loss of the expression of PPAR $\gamma$. Methods Mol Biol., 2017; 1527: 381-407.

8. Legchenko E, Chouvarine P, Borchert P, FernandezGonzalez A, Snay E, Meier M, Maegel L, Mitsialis SA, Rog-Zielinska EA, Kourembanas S, Jonigk D, Hansmann G, PPAR $\gamma$ agonist pioglitazone reverses pulmonary hypertension and prevents right heart failure via fatty acid oxidation. Sci Transl Med., 2018; 10(438): 1-18

9. Hamza AA, Fikry EM, Abdallah W, Amin A, Mechanistic insights into the augmented effect of bone marrow mesenchymal stem cells and thiazolidinediones in streptozotocin-nicotinamide induced diabetic rats. Sci Rep., 2018; 8(1): 1-18. 
10. Morisaki K, Shibata R, Takahashi N, Ouchi N, Maehara Y, Murohara T, Komori K, Pioglitazone prevents intimal hyperplasia in experimental rabbit vein grafts. J Vasc Surg., 2011; 54(6): 1753-1759.

11. Mohammadi GA, Danesh B, Fallah H, Rahemi S, The effect of co-administration of pioglitazone and simvastatin on insulin resistance parameters and PPAR $\gamma$ expression in insulin-resistant rats. J Kerman Univ Med Sci., 2017; 24(1): 16-27.

12. Langenfeld MR, Forst T, Hohberg C, Kann P, Lübben G, Konrad T, Füllert SD, Sachara C, Pfützner A, Pioglitazone decreases carotid intima-media thickness independently of glycemic control in patients with type 2 diabetes mellitus: results from a controlled randomized study. Circulation, 2005; 111(19): 2525-2531.

13. Isenovic ER, Kedees MH, Haidara MA, Trpkovic A, Mikhailidis DP, Marche P, Involvement of ERK1/2 kinase in insulin-and thrombin-stimulated vascular smooth muscle cell proliferation. Angiology, 2010; 61(4): 357-364.

14. Xiong Y, Zeng W, Protective effect of ellagic acid in vascular epoxidation damage in a murine model of atherosclerosis. Farmacia, 2019; 67(3): 490-495.

15. Kingsley K, Huff JL, Rust WL, Carroll K, Martinez AM, Fitchmun M, Plopper GE, ERK1/2 mediates PDGF-BB stimulated vascular smooth muscle cell proliferation and migration on laminin-5. Biochem Biophys Res Commun., 2002; 293(3): 1000-1006.

16. ălar DM, Pop C, Buzdugan E, Todea D, Mogoșan CI, The atherosclerosis-inflammation relationship a pathophysiological approach Farmacia, 2019; 67(6): 941-947.

17. Osman I, Segar L, Pioglitazone, a PPAR $\gamma$ agonist, attenuates PDGF-induced vascular smooth muscle cell proliferation through AMPK-dependent and AMPKindependent inhibition of mTOR/p70S6K and ERK signaling. Biochem Pharmacol., 2016; 101: 54-70. 